\title{
Gas Difusion Electrodes for PBI Cells
}

\section{Li, Qingfeng; Pan, Chao; Jensen, Jens Oluf; Nilsson, Morten Sixten; Bjerrum, Niels}

Published in:

Meeting Abstracts - Electrochemical Society

Publication date:

2006

Document Version

Publisher's PDF, also known as Version of record

Link back to DTU Orbit

Citation (APA):

Li, Q., Pan, C., Jensen, J. O., Nilsson, M. S., \& Bjerrum, N. (2006). Gas Difusion Electrodes for PBI Cells. In Meeting Abstracts - Electrochemical Society (pp. Abstract 541). The Electrochemical Society.

\section{General rights}

Copyright and moral rights for the publications made accessible in the public portal are retained by the authors and/or other copyright owners and it is a condition of accessing publications that users recognise and abide by the legal requirements associated with these rights.

- Users may download and print one copy of any publication from the public portal for the purpose of private study or research.

- You may not further distribute the material or use it for any profit-making activity or commercial gain

- You may freely distribute the URL identifying the publication in the public portal

If you believe that this document breaches copyright please contact us providing details, and we will remove access to the work immediately and investigate your claim. 
Abstract to the 210th ECS Meeting, Cancun, Mexico, October 29-November 3, 2006

\section{Gas Diffusion Electrodes for PBI Cells}

Q. Li, C. Pan, J. O. Jensen, M. Nilsson and N. J. Bjerrum

Department of Chemistry

Technical University of Denmark

Building 207, DK-2800 Lyngby, Denmark

Acid doped polybenzimidazole (PBI) membranes have been suggested as electrolyte for proton exchange membrane fuel cells (PEMFC) ${ }^{[1]}$ and received great attention, as recently reviewed. ${ }^{[2-4]}$ Fuel cell tests have been performed with different types of fuels such as hydrogen, hydrogen containing $\mathrm{CO}^{[5]}$, methanol ${ }^{[6]}$ and others. Methods for preparing gas diffusion electrodes and membrane-electrode assemblies (MEAs) with PBI membranes have been developed by several groups. The gas diffusion electrodes were constructed with PBI as the catalyst binder or, when PTFE was used as the catalyst binder, the electrodes were impregnated with PBI. The loading of the polymer in the catalyst layer is a key parameter. The PBI containing electrodes are then doped with phosphoric acid to order to improve the proton conductivity.

In this work a tapecasting method is used for preparing gas diffusion electrodes for PBI cells. The total porosity of electrodes was changed from $43 \%$ to $64 \%$ with help of porogens as additives to the catalyst slurry for electrode casting. The porosity of gas diffusion electrodes is determined by absorbing toluene into the electrodes under vacuum and measuring the weight change of the electrode samples. Fig.1 shows the porosity variation of the gas diffusion electrodes made from slurries containing various porogens. Of the selected porogens, ammonium oxalate seems to be an effective one. It decomposes completely during the drying of electrodes at $250^{\circ} \mathrm{C}$ and gives an improved overall porosity from $43 \%$ to above $60 \%$. $\mathrm{ZnO}$ is also effective, however, it should be removed afterwards by washing electrodes with dilute sulfuric acid.

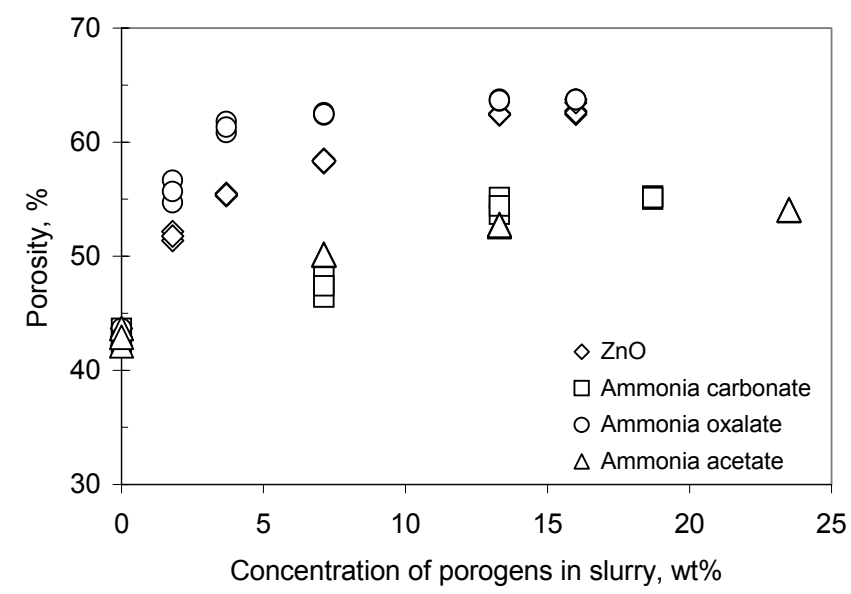

Fig.1. Total porosity of gas diffusion electrodes tapecast from slurries containing various types of porogens.

The performance of fuel cells with electrodes of varied porosities was investigated at temperatures up to $200^{\circ} \mathrm{C}$. The used fuel gases are pure hydrogen and hydrogen containing $25 \% \mathrm{CO}_{2}$ and the oxidant is either oxygen or air. The operational pressure was changed from ambient to 4 bars on both anode and cathode sides.
Fig. 2 shows a set of polarizations curves obtained from such made electrodes with an overall porosity of $43 \%$ and $62 \%$, respectively, operating on both oxygen and air at the cathode.

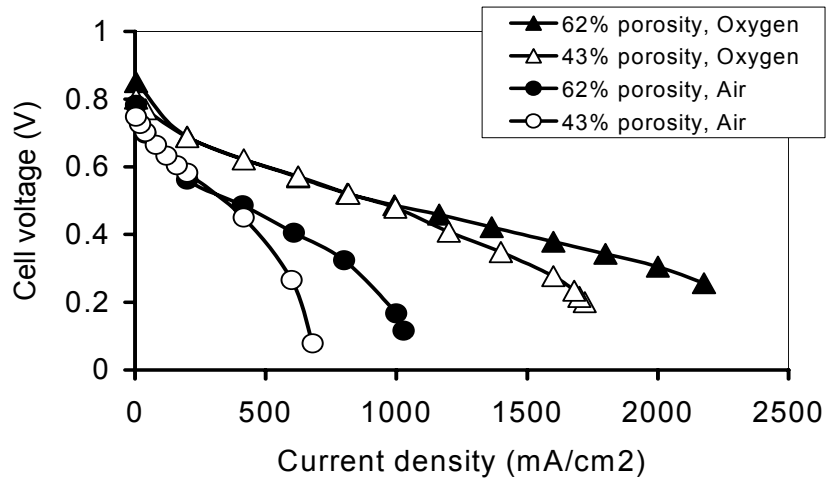

Fig.2. Polarization curves of a PBI fuel cell under ambient pressure at $200^{\circ} \mathrm{C}$. The platinum loading of each electrode was $0.6 \mathrm{mgPt} / \mathrm{cm}^{2}$. The electrode area was $25 \mathrm{~cm}^{2}$ with a gas flow rate of $24 \mathrm{~L} / \mathrm{h}^{1}$ for hydrogen and oxygen, $48 \mathrm{~L} / \mathrm{h}^{1}$ for air.

Fig. 3 shows polarizations curves obtained with electrodes of $64 \%$ porosity. With $\mathrm{O}_{2}$ at cathode, no limiting current is observed at current densities of $2.5 \mathrm{~A} / \mathrm{cm}^{2}$ and hydrogen utilization of over $93 \%$ from a mixture of $75 \% \mathrm{H}_{2}$ $25 \% \mathrm{CO}_{2}$.

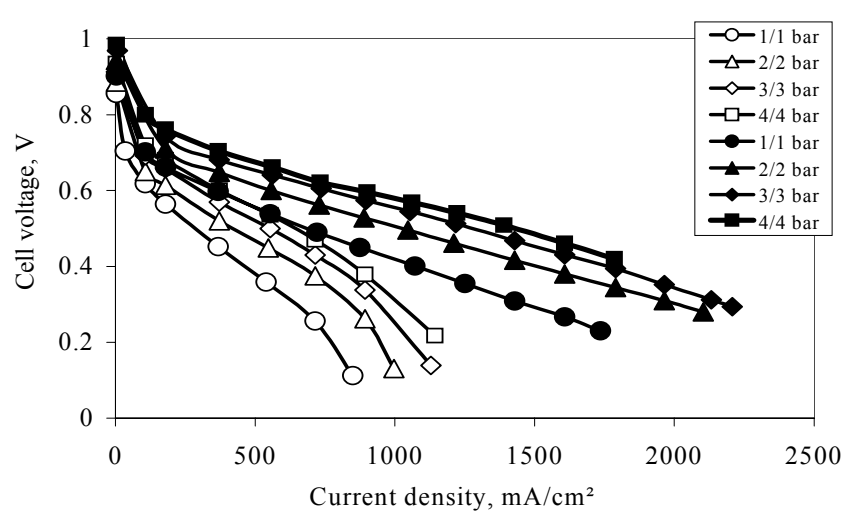

Fig.3. Polarization curves of a PBI cell under different pressures at $200{ }^{\circ} \mathrm{C}$. Fuel: $25 \% \mathrm{CO}_{2}-75 \% \mathrm{H}_{2}$; Oxidant: open symbols for air and solid symbols for $\mathrm{O}_{2}$; Active electrode area: $25 \mathrm{~cm}^{2}$; Pt loading: $0.6 \mathrm{mg} / \mathrm{cm}^{2}$; Overall electrode porosity: 64\%; Fuel flow: $10 \mathrm{~L} / \mathrm{h} ; \mathrm{O}_{2}$ flow: $4 \mathrm{~L} / \mathrm{h}$; Air flow: $8 \mathrm{~L} / \mathrm{h}$.

Acknowledgement. This work has received financial support from the European Commission (Project no. SES6-CT-2004-502782).

\section{References}

[1] J. S. Wainright, J-T. Wang, D. Weng, R. F. Savinell, M. Litt, J. Electrochem. Soc. 142 (1995) L121.

[2] J. S.Wainright, M. H. Litt, R. F. Savinell, In Handbook of FuelCells, W.Vielstichm, A.Lamm, H.A. Gasteiger Eds.; John Wiley (2003), Vol. 3, p 436.

[3] Q. Li, R. He, J. O. Jensen, J. Bjerrum, Chem. Mater. 15 (2003) 4896.

[4] Q. Li, R. He, J. O. Jensen, N. J. Bjerrum, Fuel Cells Fundam. Syst. 4 (2004) 147.

[5] Q., Li, R. He, J. Gao, J. O. Jensen, and N. J. Bjerrum, J. Electrochem. Soc. 2003, 150, A1599.

[6] J.-T. Wang, J. S. Wainright, R. F. Savinell and M. Litt, J. Appl. Electrochem. 1996, 26, 751 